$\mathrm{Y} \triangle \mathrm{K} 330.322+330.341+338.432$

S. Kbalatur,

Doctor of Economic Sciences, associate professor, Professor of Finance, Banking

and Insurance Department, Dnipro State Agrarian and Economic University

ORCID ID: 0000-0001-8331-3341

O. Dubovych,

$P h D$ in Law, Associate Professor of Entrepreneurship and Law Department

Poltava State Agrarian Academy

ORCID ID: 0000-0003-3390-1393

Yu.Kurchenko,

Student of gr. MGFBSz-1-18, Dnipro State Agrarian and Economic University

ORCID ID: 0000-0003-4111-4269

\title{
IMPROVEMENT OF BUSINESS ACTIVITY MANAGEMENT OF AGRICULTURAL ENTERPRISE AS A FACTOR FOR INNOVATION-INVESTMENT DEVELOPMENT OF AGRICULTURAL PRODUCTION
}

\section{C. М. Халатур,}

А. е. н., Аоцент, професор кафедри фінансів, банківської справи та страхування,

Аніпровський державний аграрно-економічний університет

О. В. Аубович,

к. ю. Н., Аоцент кафедри підприємництва і права,

Полтавська державна аграрна академія,

Ю. А. Курченко,

студентка гр. МГФБСз-1-18, Дніпровський державний аграрно-економічний університет

\author{
УАОСКОНАЛЕННЯ УПРАВАІННЯ АІАОВОЮ АКТИВНІСТЮ СІЛЬСЬКОГОСПОААРСЬКОГО \\ ПІАПРИЕМСТВА ЯК ФАКТОР РОЗВИТКУ ІННОВАЦІЙНО-ІНВЕСТИЦІЙНОЇ АІЯЛЬНОСТІ \\ АГРОПРОМИСАОВОГО ВИРОБНИЦТВА
}

\footnotetext{
Approaches to determining the nature of business activity are generalized. Factors of influence on business activity are considered. Improving the business activity management of an agricultural enterprise as a factor in the development of innovation and investment activity of agro industrial production is an extremely relevant topic, since business activity is the totality of the enterprise's efforts to advance in the markets of production, labor, and capital. Internal and external factors of influence on business activity of the enterprise can be both managed and unmanaged depending on the type to which they belong. Thus, if an enterprise is able to influence internal factors, they can be adjusted depending on the tactical and strategic tasks of the entity and vice versa. If they are of external origin, the enterprise is able to adapt and adapt to them.

Solving the problems of agricultural products entering the new markets, the need to increase the level of competitiveness of domestic enterprises in the context of strengthening the European integration processes and the implementation of national economic strategies in the system of European economic relations of the common agrofood market is based on solving the problems of attraction and accumulation. The practical solution of these problems in modern conditions is carried out in the context of ensuring the investment flows and their optimization, which is conditioned by the specificity and dynamic parameters of the development of agricultural enterprises.

The purpose of the study is to highlight the prerequisites for improving the management system of business activity of an agricultural enterprise as a factor in the development of innovation and investment activity of agro-industrial production.

For a more detailed disclosure of the topic of the study, the indicators of agricultural enterprises of Ukraine for the calculation of business activity were analyzed. Business activity reflects the usage efficiency level of material, labor, financial and other resources and at the same time characterizes the quality of management, as well as the possibilities of potential development of the enterprise.
}

Узагальнено Підходи до визначення сутності ділової активності. Розглянуто фактори впливуна ділову ак-

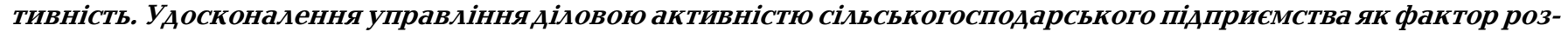
витку інноваційно-інвестиційної, діяьності агропромислового виробництва є надзвичайно актуальною темою, 
оскільки ділова активність є всією сукупністю зусиль підприємства щодо просування на ринках продукції, праці, капіталу. Внутрішні та зовнішні фактори вПливу на ділову активність підприемства можуть бути як керованими, так і некерованими залежно від виду, до якого вони відносятьСя. Так, якщо підприємСтво має змогу вПливати на внутрішні фактори, то вони можуть бути відкориговані залежно від тактичних та стратегічних завдань суб' єкта ПідПриємництва та навпаки. Якщо вони мають зовнішне походження, то підПриємСтво в змозі адаптуватися та пристосуватися до них.

Вирішення завдань виходу Продукцї̈ сільСькогосподарських підприємСтв на нові ринки, необхідність підвищення рівня конкурентоспроможності вітчизняних підприємств У контексті посилення євроінтеграційних процесів та імплементації національних стратегій господарювання у систему європейських економічних відноСин СПільного агропродовольчого ринку грунтуєтьСя на вирішенні проблеми залучення, акумУлювання, розміщення та використання інвестиційних та інноваційних ресурсів. Практичне вирішення зазначених проблем Усучасних Умовах здійснюеться в контексті забезпечення кругообігу інвестиційних потоків та їх оптимізаціі, що зУмовлюєтьСя СПецифікою та динамічними Параметрами розвиткУ СільСькогосподарСьких ПідприємСтв.

Мета дослідження полягає У виокремленні передумов Удосконалення Системи управління діловою активністю СіАьСькогосподарського ПідприемСтва як фактору розвиткУ інноваційно-інвестиційної діяльності агропромислового виробництва.

Аля більш детального розкриття теми дослідження проаналізовано показники СільСькогосподарських підприємств України для розрахунку ділової активності. Аілова активність відображає рівень ефективності використання матеріальних, трудових, фінансових і інших ресурсів і водночаС характеризує якість управління, а також можАивості потенційного розвиткУ підприємства.

Key words: modernization, innovative activity, investments, development, agriculture.

Ключові слова: модернізачія, інновачійна діяльність, інвестичї, розвиток, сільське господарство.

\section{INTRODUCTION}

Innovation-investment development and competitiveness of agricultural enterprises in modern conditions are largely determined by the business activity of agricultural enterprises. Business activity has undergone significant changes in the course of the evolution of the world economy and has become one of the main tools by which it is possible to objectively determine the efficiency of financial activity of enterprises and the prospects for their development. Business activity covers the most important spheres of life of enterprises: production, finance, and marketing.

Thus, improving the management of business activity of an agricultural enterprise as a factor in the development of innovation and investment activity of agro-industrial production is an extremely relevant topic, since business activity is the totality of the enterprise's efforts to advance in the markets of production, labor, and capital. Internal and external factors of influence on business activity of the enterprise can be both managed and unmanaged depending on the type to which they belong. Thus, if an enterprise is able to influence internal factors, they can be adjusted depending on the tactical and strategic tasks of the entity and vice versa. If they are of external origin, the enterprise is able to adapt and adapt to them.

Solving the problems of agricultural products entering new markets, the need to increase the level of competitiveness of domestic enterprises in the context of strengthening the European integration processes and the implementation of national economic strategies in the system of European economic relations of the common agro-food market is based on solving the problems of attraction, accumulation and accumulation. The practical solution of these problems in modern conditions is carried out in the context of ensuring the flow of investment flows and their optimization, which is conditioned by the specificity and dynamic parameters of the development of agricultural enterprises.

\section{ANALYSIS OF RECENT RESEARCH AND PUBLICATIONS}

Problems of innovation and investment development of agricultural production were investigated by such scientists V.G. Andriychuk, V.A. Borisova, M.L. Varlamova, M.O. Gomenyuk, M.Ya. Demyanenko, I.O. Kryukova, B. V. Po- grischuk, P.T. Sabluk, L.A. Fedulova, T.A. Gray, M. Boehlje, J. Fulton, D. Spielman, D. and others.

In recent years, scientists have also increasingly turned their attention to the problems of defining the nature, management and evaluation of business activity of enterprises. In particular, these issues were studied by such scientists as: I.O. Blank, M.P. Voinarenko, G.G. Kireytsev, V.V. Kovalev, EV Mnykh, A.D. Sheremet and others.

Thus, Viktoriia Koilo and Ola Honningdal Grytten (2019) investigate the role of financial instability and the consequences of the evolution of the supply chain. The researchers used time series of activity levels and the main financial indicators of income from turnover and equity, debt to assets ratio.

Oksana Tulai, Yuriy Petrushenko, Jozef Glova, Iryna Sydor and Oksana Ponomarenko (2019) study the growing differentiation in the functioning of the economy of the Ukrainian regions and the introduction of decentralization mechanisms in the sphere of relations between central and local authorities regarding changes in the approaches to financial support. The potential of regions reflecting the level of economic development of certain territories is particularly important. Because financial support for the development of Ukrainian regions depends on the ability of economic entities to shape and enhance their financial potential, the effectiveness of financial resources management and social, economic, environmental and political factors through destabilization processes in the country.

Kateryna Andriushchenko, Mariia Tepliuk, Svitlana Boniar, Natalya Ushenko and Anastasiia Liezina (2019) argue that the development of a business environment offers opportunities for capital market participants. Objectives of value-oriented management of investment activity of the enterprise: increase in capitalization, increase in value. Accordingly, all company decisions should be aimed at achieving these goals.

Olena Iastremska, Hanna Strokovych, Oleksiy Dzenis, Olena Shestakova and Timur Uman (2019) write that current socio-economic processes are characterized by variability, chance, riskiness, dynamism and increasing tendency of their changes. This applies to all aspects of modern economics and management, namely: financial and economic, social, innovative, technical, technological. Therefore, it is necessary to carefully study the subject areas of singularity in economics and management related to investment and innovation processes. 


\section{HIGHLIGHTING PREVIOUSLY UNRESOLVED PARTS OF A COMMON PROBLEM}

At the same time, the complexity, multidimensionality and multifunctionality of the development of agro industrial production requires further justification and improvement of the system of management of business activity of an agricultural enterprise as a factor of development of innovation and investment activity of agro industrial production. The main determinant in this case is the innovative transformation on the basis of attracting investment flows, which requires fur ther scientific and applied research.

The purpose of the study is to identify the prerequisites for improving the management system of business activity of an agricultural enterprise as a factor in the development of innovation and investment activity of agroindustrial production.

\section{PRESENTING MAIN MATERIAL}

For the purposes of the study, we define the business activity of the enterprise as a complex concept, which is the result of the interaction of all elements of the system of financial relations of the enterprise, is determined by a set of production and economic factors and characterized duction and economic factors and characterized placement and use of financial resources. To date, busines activity is considered from three positions: the individual; enterprise (micro level); country (macro level).

In Fig. 1 it is shown a diagram of the business activity management influence of an agricultural enterprise on the innovation-investment development of agro-industrial production.

At the enterprise level, business activity is most often seen as the performance of an enterprise in terms of the amount of resources advanced or their consumption in the production process. Business activity reflects the level of efficiency of use of material, labor, financial and other resources and at the same time characterizes the quality of management, as well as the possibilities of potential development of the enterprise.

Therefore, business activity is one of the most important characteristics of the functioning and development of the enterprise. The lack of a unified approach to defining this concept testifies to the imperfect categorical apparatus of this important economic category. With regard to business management, it requires the main areas of consideration for which it is carried out and an assessment of the specifics of each. Assessment of business activity is advisable to carry out with the help of the following groups of indicators: indicators of turnover, fund return, profitability, measures of crisis management, financial status, efficiency, because they characterize all areas of financial and economic activity of the enterprise. In general, there are three types of business activity that are associated with three financial and economic situations in the enterprise: high business activity, which is a sign of normal status, medium problem and low - crisis.

Carrying out any activity of the enterprise, the weakening of which will lead to a decrease in financial stability, a decrease in

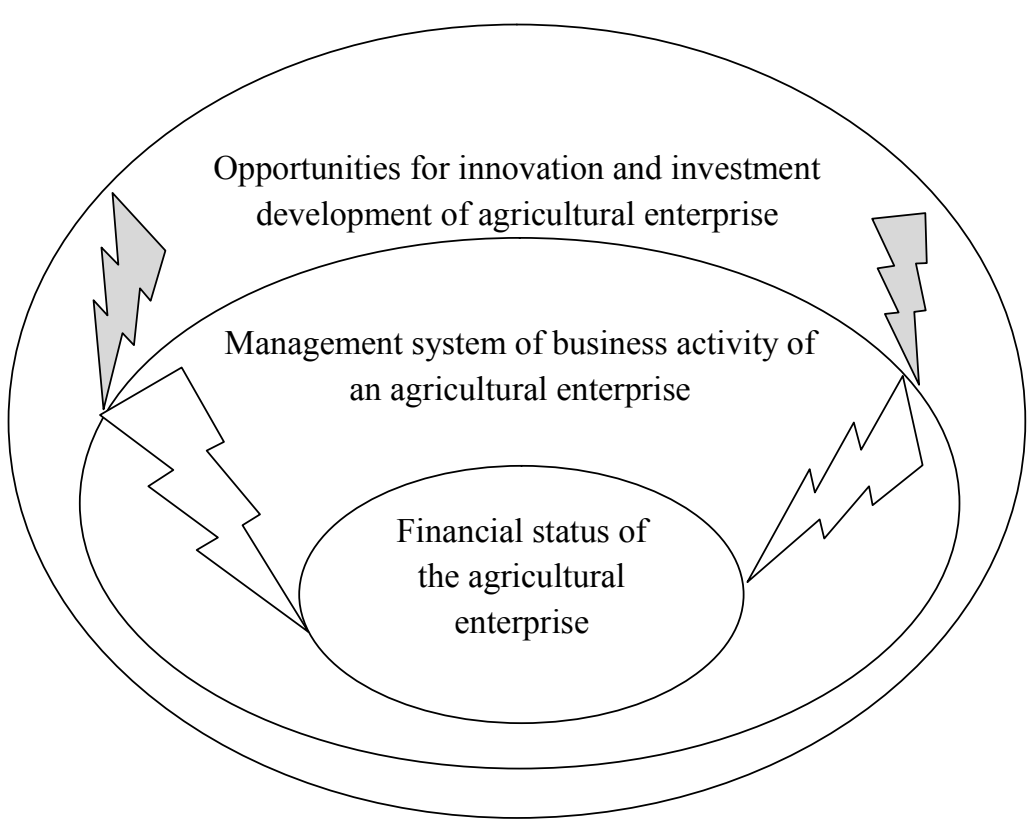

Fig. 1. Diagram of the business activity management influence of an agricultural enterprise on the innovation-investment development of agro-industrial production

Source: own authors' development.

liquidity, a deterioration of the solvency and business activity of the enterprise, which will lead to losses, decrease in profitability and losses. The innovation and investment aspect is expressed in terms of functional components that characterize the threats of internal and external origin.

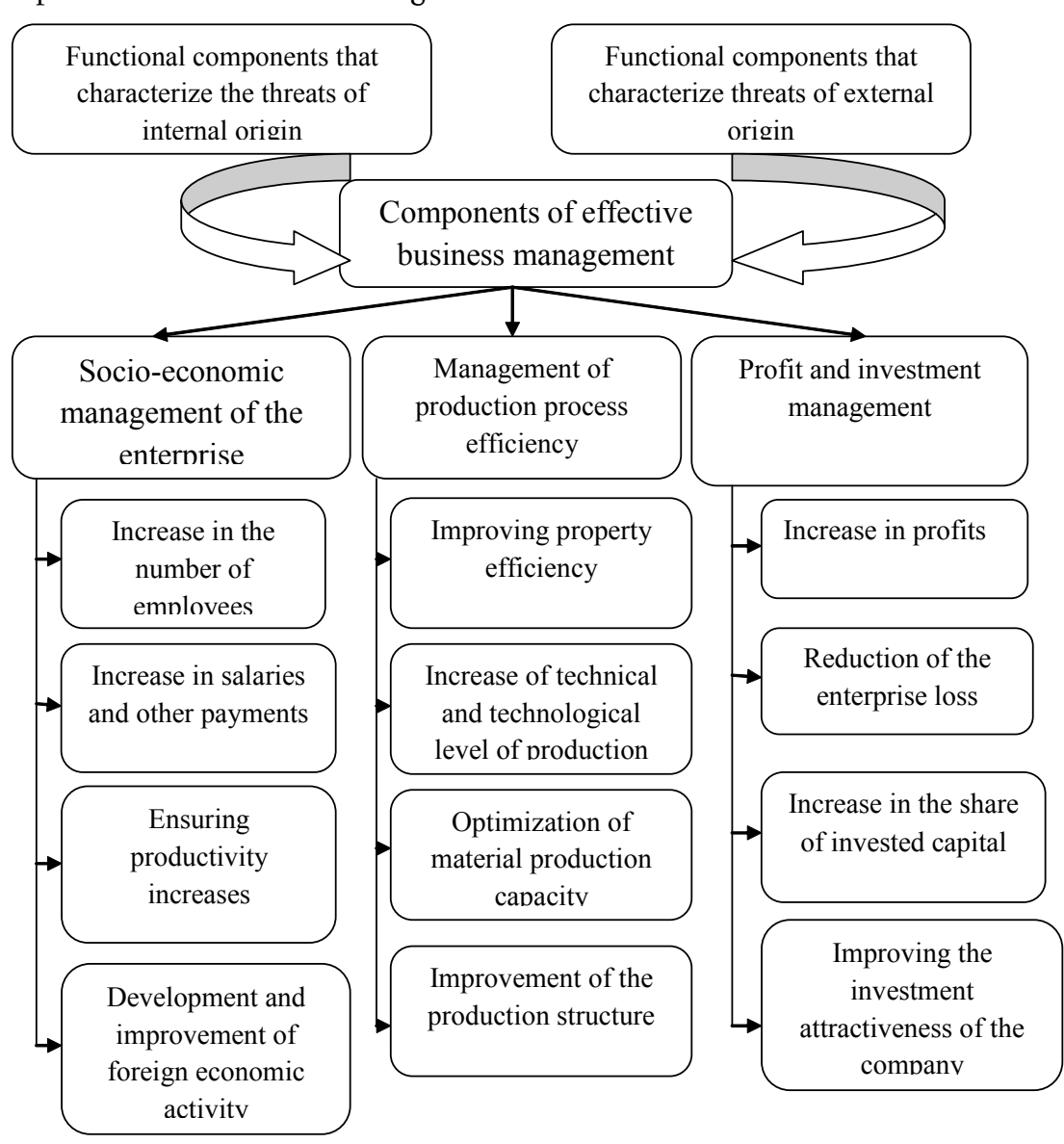

Fig. 2. Components of effective management of the business activity of an agricultural enterprise

Source: own authors' development. 


\section{ЕКОНОМІЧНА НАУКА}

In the short term, the strategic goal of managing the business activity of an agricultural enterprise should be to overcome the economic and structural crisis. An integrated approach is required to achieve effective business management:

1. Environmental safety: a strategic goal is to preserve and restore natural ecosystems, stabilize and improve the quality of the environment, reduce emissions of harmful substances, etc.

2. Economic stability: the aim is to create a socially and environmentally efficient agricultural enterprise that ensures a decent level and competitiveness of production.

3. Social well-being: The main goal is to improve the human environment, to develop social activity, to ensure equal opportunities in health care, and to socially protect vulnerable populations. In the long run, the emphasis of development will shift from economic to environmental, social and material to informational.

For a more detailed explanation of the study topic, in Table 1 there are analyzed the indicators of Ukrainian agricultural enterprises to calculate business activity.

In Fig. 3 it is graphically shown the dynamics of revenues, current assets and receivables of agricultural enterprises of Ukraine.

Business activity of the enterprise in the financial aspect is manifested primarily in the speed of turnover of its funds. Analysis of business activity is to study the levels and dynamics of various turnover ratios, the main of which are:

- Asset turnover ratio;

- Working capital ratio;

- Receivables turnover ratio;

- Ratio of accounts payable;

- Inventory turnover ratio;

- Turnover ratio of fixed assets;

- Equity ratio.

The importance of turnover is explained by the fact that turnover characteristics largely determine the level of profitability of the enterprise.

In Table 2 there are analyzed the indicators of business activity of agricultural enterprises of the national economy of Ukraine.

Thus, the ratio of assets turnover - reflects the speed of turnover of the total capital of the enterprise, that is, shows how many times during the analyzed period a complete cycle of production and turnover, which brings the corresponding effect in the form of profit, or how many units of sales produced each unit of assets:

$\mathrm{CoA}=$ Net Sales Revenue / Average Asset Value.

The turnover ratio of current assets describes the ratio of revenue (gross income) from the sale of products, excluding value added tax and excise duty to the amount of current assets of the enterprise. A decrease in this ratio indicates a slowdown in working capital turnover.

Receivables turnover ratio. In the course of economic activity, the enterprise gives commodity credit to the consumers of its products, that is, there is a gap in time between the sale of goods and the receipt of payment for them, resulting in receivables. The receivables turnover ratio shows how many times a year the funds invested in the calculations have turned. As a rule, the higher this figure, the better, because the company is quicker to pay the bills. On the other hand, the provision of commodity credit to buyers is one of the tools to promote sales, so it is important to find the optimal length of the credit period.

\section{activity, mln. hrn.}

\begin{tabular}{|l|l|l|c|c|c|c|l|}
\hline \multicolumn{1}{|c|}{2013} & 2014 & 2015 & 2016 & 2017 & 2018 & $\begin{array}{c}\text { Change, } \\
\%\end{array}$ \\
\hline 78301,8 & 87659,2 & 104764,3 & 146363,6 & 141341,9 & 184137,9 & 235,16 \\
\hline 195021,3 & 261814,7 & 514624,6 & 553429,0 & 639025,2 & 8579,7 & 4,40 \\
\hline 93808,1 & 151461,0 & 342782,5 & 1092111,3 & 331508,1 & 365703,9 & 389,84 \\
\hline & 47268,4 & 72116,0 & 129075,4 & 172120,3 & 156840,4 & 186827,6 & 395,25 \\
\hline & 63559,0 & 84446,9 & 112447,2 & 160251,5 & 157133,4 & 203408,0 & 320,03 \\
\hline & 15147,3 & 21677,4 & 103137,6 & 91109,5 & 69344,1 & 71478,5 & 471,89 \\
\hline & 156820,0 & 156700,4 & 275303,8 & 370158,0 & 436337,7 & 110081 & 70,20 \\
\hline
\end{tabular}

to calculate business

Source: compiled by the authors according to the State Statistics Service of Ukraine.

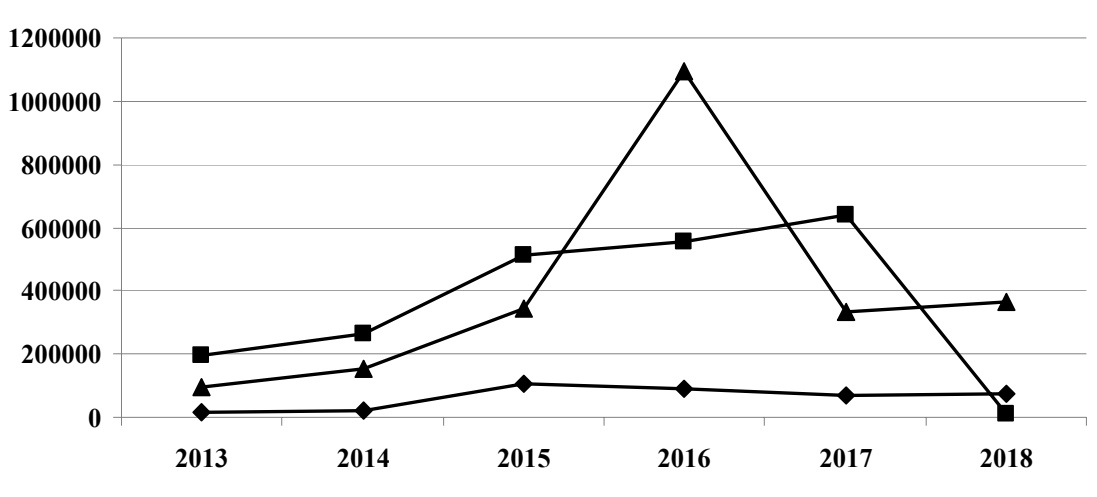

Виручка від реалізації $\rightarrow$ Оборотні активи $\rightarrow-$ Дебіторська заборгованість

ues, current assets and receivables of agricultural enterprises of Ukraine

Table 2. Indicators of business activity of agricultural enterprises of the national economy of Ukraine

\begin{tabular}{|l|l|l|l|l|l|l|l|}
\hline \multicolumn{1}{|c|}{ Indicator } & 2013 & 2014 & 2015 & 2016 & 2017 & 2018 & $\begin{array}{c}\text { Change, } \\
\%\end{array}$ \\
\hline Asset turnover ratio & 0,06 & 0,06 & 0,17 & 0,13 & 0,09 & 0,37 & 669,26 \\
\hline $\begin{array}{l}\text { The turnover ratio of } \\
\text { current assets }\end{array}$ & 0,08 & 0,08 & 0,20 & 0,16 & 0,11 & 8,33 & 10726,31 \\
\hline Receivables turnover ratio & 0,16 & 0,14 & 0,30 & 0,08 & 0,21 & 0,20 & 121,05 \\
\hline Ratio of accounts payable & 0,32 & 0,30 & 0,80 & 0,53 & 0,44 & 0,38 & 119,39 \\
\hline $\begin{array}{l}\text { Inventory turnover ratio } \\
\text { Turnover ratio of fixed } \\
\text { assets }\end{array}$ & 0,24 & 0,26 & 0,92 & 0,57 & 0,44 & 0,35 & 147,45 \\
\hline Equity turnover ratio & 0,10 & 0,14 & 0,37 & 0,62 & 0,49 & 0,39 & 200,66 \\
\hline
\end{tabular}

Source: calculated by the authors according to according to the State

Accounts receivable turnover is useful to compare with accounts payable. This approach makes it possible to compare the terms of the commercial credit given by the analyzed enterprise to its customers with the credit terms used by the suppliers. To do this, it is necessary to determine the ratio of turnover and turnover of receivables and payables on commodity transactions.

Accounts Payable Ratio - indicates the expansion or decrease of a commercial loan granted to an enterprise. An increase in the ratio means an increase in the rate of payment of debt of the enterprise, a decrease - an increase in purchases on credit.

Inventory turnover ratio - reflects the number of turnover of inventories of the enterprise for the analyzed period. The decrease in this indicator indicates a relative increase in inventories and work in progress or a decrease in demand for finished products. In general, the higher the inventory turnover rate, the less money is tied up in this least liquid item of current assets, the more liquid the current assets have and the more stable the financial position of the enterprise.

The turnover ratio of fixed assets (return on assets) is calculated as the ratio of net proceeds from 
the sale of products (works, services) to the average annual cost of fixed assets. It shows the efficiency of use of fixed assets of the enterprise. Equity turnover ratio is calculated as the ratio of net proceeds from the sale of products (works, services) to the average annual value of the enterprise's own capital and characterizes the efficiency of using the enterprise's own capital.

\section{CONCLUSIONS AND PROSPECTS FOR FURTHER RESEARCH}

Based on the study, the following conclusions can be drawn. Innovation and investment development of the agro-industrial complex is an important element of innovation and investment in agricultural enterprises, which in turn will contribute to economic growth and food security. A wide range of investors are involved in investments in agricultural enterprises; therefore, it is important to ensure not only the growth of investments (especially private ones), but also the sustainable and socially responsible nature of these investments. Agricultural investment and regulatory policies must be well-established and effectively implemented in order to bring social and economic benefits to the agricultural enterprise and the country as a whole, including the growth of welfare and the safeguarding of the rational use of natural resources.

The direction of further research should be to explore the possibility of improving the investment climate for the innovative development of Ukrainian agricultural enterprises.

\section{$\Lambda$ ітература:}

1. Аемчук H.I., Халатур C.M., Хідірян M.O. Теоретичні основи аналізу фінансового стану сільськогосподарських підприємств. Економіка та суспільство. 2017. 9. С. $396-400$.

2. Аержавний сайт статистики України. URL: http:/ /www.ukrstat.gov.ua/

3. Аілова активність підприємства: сутність та методика аналізу: монографія / Н.Б. Кащена, О.О. Горошанська, Т.В. Польова [та ін.]. - Х.: Видавництво Іванченка I.C., 2016. - 196 с.

4. Мєшкова Н.А. Оцінка ділової активності підприємства на макрорівні / Н.А. Мєшкова // Глобальні та національні проблеми економіки. - 2015. - Вип. 5. C. $508-511$.

5. Acharya V. \& Plantin G. (2017). Monetary easing and financial instability (Discussion Paper, No. 63). Retrieved from http://eprints.lse. ac.uk/70715/1/dp-63.pdf

6. Andriushchenko K., Tepliuk M., Boniar S., Ushenko N. and Liezina A. (2019). Influence of cost drivers on value-oriented management of investment activity of companies. Investment Management and Financial Innovations, 16 (3), 353-364. doi:10.21511/imfi.16(3).2019.31

7. Iastremska O., Strokovych H., Dzenis O., Shestakova O. and Uman T. (2019). Investment and innovative development of industrial enterprises as the basis for the technological singularity. Problems and Perspectives in Management, 17(3), 477-491. doi:10.21511/ppm.17(3).2019.38

8. Iastremska O.M. \& Stokovych H. (2019). Main trends of investment and innovative activity of business entities in the conditions of European integration. Innovative Tachnologies and Scientific Solutions for Industries, 1 (7). https://doi.org/10.30837/2522-9818.2019.7.130

9. Hudym K., Khalatur S. (2016). Systematisation and analysis of MNCs' models of conduct for entering the national agrarian markets. Економічний часопис-XXI, $5-6,34-37$.

10. Khalatur S. (2015). Mechanism of adaptation of agroindustrial complex of Ukraine in the conditions of global food problem. Visnyk Dnipropetrovs' koho derzhavnoho ahrarno-ekonomichnoho universytetu, 1, $114-116$.

11. Khalatur S.M. (2017). Innovative doctrine development of agriculture growth of Ukraine. Технологический аудит и резервы производства. Vol. 4, 5 (36), $19-26$.

12. Koilo V. and Ola Honningdal Grytten (2019). Maritime financial instability and supply chain management effects. Problems and Perspectives in Management, 17 (4), 62-79. doi:10.21511/ppm.17(4).2019.06.

13. Tulai O., Petrushenko Yu., Glova J., Sydor I. and Ponomarenko O. (2019). The impact of decentralization on the financial support of regional development. Investment Management and Financial Innovations, 16 (4), 1-15. doi:10.21511/imfi.16(4).2019.01.

\section{References:}

1. Demchuk, N.I. Khalatur, S.M. and Khidiryan, M.O. (2017), "Theoretical bases of analysis of the financial state of agricultural enterprises", Economics and Society, vol. 9, pp. 396-400.

2. State Statistics Service of Ukraine (2019), available at: http://www.ukrstat.gov.ua/ (Accessed 10 Nov 2019).

3. Kaschena, N.B. Horoshans'ka, O.O. and Pol'ova, T.V. (2016), Dilova aktyvnist' pidpryiemstva: sutnist' ta metodyka analizu [Business activity of the enterprise: essence and method of analysis], Vydavnytstvo Ivanchenka I.S., Kharkiv, Ukraine.

4. Meshkova, N.L. (2015), "Assessment of business activity of the enterprise at the macro level", Global and national problems of economy, vol. 5, pp. 508-511.

Acharya, V. and Plantin, G. (2017), "Monetary easing and financial instability", Discussion Paper, vol. 63, available at: http:// eprints.lse.ac.uk/70715/1/dp-63.pdf (Accessed 10 Nov 2019).

5. Andriushchenko, K. Tepliuk, M. Boniar, S. Ushenko N. and Liezina A. (2019), "Influence of cost drivers on value-oriented management of investment activity of companies. Investment Management and Financial Innovations", vol. 16 (3), pp. 353-364. doi:10.21511/ imfi.16(3).2019.31

6. Iastremska, O. Strokovych, H. Dzenis, O. Shestakova O. and Uman T. (2019), "Investment and innovative development of industrial enterprises as the basis for the technological singularity", Problems and Perspectives in Management, vol. 17(3), pp. 477-491. doi:10.21511/ppm.17(3).2019.38

7. Iastremska, O. M., \& Stokovych, H. (2019), "Main trends of investment and innovative activity of business entities in the conditions of European integration", Innovative Tachnologies and Scientific Solutions for Industries, vol.1(7). https://doi.org/10.30837/2522-9818.2019.7.130

8. Hudym, K. and Khalatur, S. (2016), "Systematisation and analysis of MNCs' models of conduct for entering the national agrarian markets", Economic Annals -XXI, vol. 5 6, pp. 34-37.

9. Khalatur, S. (2015), "Mechanism of adaptation of agroindustrial complex of Ukraine in the conditions of global food problem", Visnyk Dnipropetrovs'koho derzhavnoho ahrarno-ekonomichnoho universytetu, vol. 1, pp. $114-116$.

10. Khalatur, S.M. (2017), "Innovative doctrine development of agriculture growth of Ukraine", Technological audit and production reserves, vol. 4, no. 5 (36), pp. 19-26.

11. Koilo, V. and Honningdal Grytten, O. (2019), "Maritime financial instability and supply chain management effects", Problems and Perspectives in Management, vol. 17 (4), pp. 62-79. doi:10.21511/ppm.17(4).2019.06

12. Tulai, O. Petrushenko, Yu. Glova, J. Sydor I. and Ponomarenko O. (2019), "The impact of decentralization on the financial support of regional development", Investment Management and Financial Innovations, vol. 16 (4), pp. 1-15. doi:10.21511/imfi.16(4).2019.01

Стаття надійшла до редакиї 28.11.2019 р. 